Pesq. Vet. Bras. 37(1):41-46, janeiro 2017

DOI: 10.1590/S0100-736X2017000100007

\title{
Evaluation of the concentration of allergens from mites in fur and households dust of dogs with atopic dermatitis ${ }^{1}$
}

\author{
Dévaki L. de Assunção ${ }^{2 *}$, Marconi R. de Farias ${ }^{3}$, Michelle C.R. Barbosa ${ }^{4}$ \\ and Luiz H. de Araújo Machado ${ }^{5}$
}

\begin{abstract}
Assunção D.L., Farias M.R., Barbosa M.C.R. \& Machado L.H.A. 2017. Evaluation of the concentration of allergens from mites in fur and households dust of dogs with atopic dermatitis. Pesquisa Veterinária Brasileira 37(1):41-46. Mestrado em Ciência Animal, Escola de Ciências Agrárias e Medicina Veterinária, Pontifícia Universidade Católica do Paraná, BR-376 Km 14, São José dos Pinhais, PR 83010-500, Brazil. E-mail: devaki.la@hotmail.com

This study evaluated the concentration of Der p 1, Der f 1 and Blo t 5 in the fur and households of 20 dogs with atopic dermatitis (AD) and 20 healthy dogs. The diagnosis of $\mathrm{AD}$ was clinical based on Favrot's criteria. Dust samples were collected with a domestic vacuum cleaner. For each site, $1 \mathrm{~m}^{2}$ was vacuumed for $2 \mathrm{~min}$. The samples were collected in separate filters, transferred into plastic containers, sealed and kept frozen until ELISA analysis. In the fur of atopic dogs the average concentration of Der $\mathrm{p} 1$ was $0.25 \mu \mathrm{g} / \mathrm{g}$ compared to $0.03 \mu \mathrm{g} / \mathrm{g}$ in healthy dogs. In households with atopic dogs the highest concentrations of Der p 1 were found in carpets $(2.18 \mu \mathrm{g} / \mathrm{g})$, followed by couches $(1.53 \mu \mathrm{g} / \mathrm{g})$, beds $(1.14 \mu \mathrm{g} / \mathrm{g})$, dogs' bed linen $(0.64 \mu \mathrm{g} / \mathrm{g})$ and floors $(0.14 \mu \mathrm{g} / \mathrm{g})$. The concentrations of Der $\mathrm{p} 1$ on carpets, couches and beds were significantly higher than in atopic dogs' fur $(\mathrm{p}<0.05)$. There was no statistical difference when comparing the concentrations of Der $f 1$ and Blo $t 5$ in different environments of atopic dogs ( $>>0.05)$. The concentrations of Der p 1, Der f 1 and Blo t 5 were equivalent in atopic and non-atopic dog's households. Among the allergens studied, Der $\mathrm{p} 1$ was the most commonly found, predominantly in carpets and couches.
\end{abstract}

INDEX TERMS: Allergens, mites, fur, household dust, dogs, atopic dermatitis.

RESUMO.- [Avaliação da concentração de alérgenos provenientes de ácaros na pelagem e na poeira de domicílios de cães com dermatite atópica.] 0 presente estudo avaliou a concentração de Der p 1, Der f 1 e Blo t 5, na pelagem e no ambiente domiciliar de cães com dermatite atópica (DA). Para tal, foram selecionados 20 cães com DA

\footnotetext{
${ }^{1}$ Received on October 27, 2015.

Accepted for publication on May 19, 2016.

${ }^{2}$ Mestrado em Ciência Animal, Escola de Ciência Agrárias e Medicina Veterinária, Pontifícia Universidade Católica do Paraná (PUCPR), BR-376 Km 14, São José dos Pinhais, PR 83010-500, Brazil. *Corresponding author: devaki.la@hotmail.com

${ }^{3}$ Departamento de Clínica Médica de Animais de Companhia, Escola de Ciência Agrárias e Medicina Veterinária, PUCPR, BR-376 Km 14, São José dos Pinhais, PR 83010-500, Brazil.

${ }^{4}$ Faculdade de Medicina de Ribeirão Preto, Universidade de São Paulo (USP), Av. Bandeirantes 3900, Monte Alegre, Ribeirão Preto, SP 14049900, Brazil.

${ }^{5}$ Departamento de Clínica Veterinária, Faculdade de Medicina Veterinária e Zootecnia, Universidade Estadual Paulista (Unesp), Distrito de Rubião Junior s/n, Cx. Postal 560, Botucatu, SP 18618-970, Brazil.
}

e 20 cães saudáveis, e seus domicílios. 0 diagnóstico de DA foi baseado nos critérios de Favrot. As amostras de poeira foram colhidas com um aspirador de pó doméstico. Para cada local de colheita, foi aspirado $1 \mathrm{~m}^{2}$ por dois minutos. As amostras foram recolhidas em filtros separadamente, transferidas para envelopes plásticos, seladas e mantidas congeladas até serem analisadas pelo método de ELISA. Na pelagem dos cães com DA, a concentração média de Der p 1 foi de $0,25 \mu \mathrm{g} / \mathrm{g}$ de poeira e nos cães saudáveis foi de $0,03 \mu \mathrm{g} / \mathrm{g}$. No ambiente de cães com DA, o Der p 1 foi encontrado em maior concentração média no tapete $(2,18 \mu \mathrm{g} / \mathrm{g})$, seguido pelo sofá $(1,53 \mathrm{~g} / \mathrm{g})$, cama $(1,14 \mu \mathrm{g} / \mathrm{g})$ e roupa de cama dos cães $(0,64 \mu \mathrm{g} / \mathrm{g})$ e chão $(0,14 \mu \mathrm{g} / \mathrm{g})$. As concentrações de Der $\mathrm{p} 1$ no tapete, sofá e cama dos cães foram significativamente maiores que na pelagem de cães com dermatite atópica $(\mathrm{p}<0,05)$. Enquanto que, não houve diferença estatística quando comparadas as concentrações de Der f 1 e Blo t 5 nos diferentes ambientes avaliados $(p>0,05)$. As concentrações de alérgenos Der p 1, Der f 1 e Blo $t 5$ se equivaleram em ambientes de cães com DA e saudáveis. En- 
tre os alérgenos estudados, o Der $\mathrm{p} 1$ foi o mais comumente encontrado, prevalecendo no tapete e no sofá.

TERMOS DE INDEXAÇÃO: Alérgenos, ácaros, pelagem, poeira, cães, dermatite atópica.

\section{INTRODUCTION}

Atopic dermatitis (AD) is an inflammatory and pruritic dermopathy which is chronic, recurrent, and highly incident amongst dogs (Olivry et al. 2010). Despite its multifactorial origins, the physiopathology of this disease is associated with genetic mutations that lead to alterations in the final keratinization of the epidermis and skin barrier dysfunction, and these changes facilitate the transepidermal penetration of environmental allergens, microbial antigens, and primary irritants and exacerbate innate and adaptive immune responses (Hillier 2002, Akdis et al. 2006, Cork et al. 2006, Olivry et al. 2010).

House dust mite allergens (HDMA) are the main factors responsible for the sensitization and development of symptoms of allergic disease in humans (Zavadniak 2000). The most common are the allergens from the mites Dermatophagoides pteronyssinus (D. pteronyssinus) and Dermatophagoides farinae ( $D$. farinae); these allergens can have epithelial origin, but they can also be enzymes (Arlian \& Platts-Mills 2001). The major allergens of mites D. pteronyssinus and $D$. farinae belong to Group 1 (Der $\mathrm{p} 1$ and Der f 1 ) and Group 2 (Der $\mathrm{p} 2$ and Der f 2 ) respectively (Madhurantakam et al. 2010).

Exposure to Der p 1 in concentrations higher than $2 \mu \mathrm{g} / \mathrm{g}$ of dust is considered a risk factor for sensitization (Eggleston \& Arruda 2003) and concentrations above 10 $\mu \mathrm{g} / \mathrm{g}$ can cause clinical manifestations of allergies in humans (Upham \& Holt 2005). Moreover, allergens from the mite Blomia tropicalis (B. tropicalis), have been implicated in the sensitization of susceptible individuals in regions with tropical or subtropical climates (Cunha et al. 2012).

The majority of dogs with AD have IgE immunoglobulins against environmental allergens that can be detected by using intradermal testing (IDT) and/or allergen-specific IgE serology (ASIgES) (Halliwell 2006, Farmaki et al. 2012). Based on the high frequency of positive results in the IDT and ASIgES tests for house dust mites, such as D. farinae and D. pteronyssinus in dogs, these mites have been considered important sources of environmental allergens associated with atopic eczema worldwide (Hill \& DeBoer 2001, Farmaki et al. 2012).

The presence of the aforementioned mite species and their allergens, including Der f 1, Der p 1, and Group 2 allergens, has been previously confirmed in the bedding, skin, hair coat, and dry food of clinically healthy dogs (Eaton et al. 1985, Randall et al. 2003, Brazis et al. 2008). Meanwhile, only few studies have attempted to determine the concentration of mite allergens in the fur and household microenvironment of dogs with $\mathrm{AD}$.

The objective of this study was to evaluate the concentration of allergens from the mites D. pteronyssinus (Der $\mathrm{p}$ 1), D. farinae (Der f 1 ), and B. tropicalis (Blo t 5 ) in the fur and households of dogs with AD.

\section{MATERIALS AND METHODS}

Sample population. The sample was composed of 20 dogs with $\mathrm{AD}, 20$ healthy dogs, and the dogs' respective households in the city of Curitiba, state of Paraná (PR), Brazil.

The AD diagnosis was based on the medical history and clinical examination, and the dogs included in the study met at least six of the eight criteria established by Favrot (Favrot et al. 2010). Further, the dogs' symptoms had not significantly improved (as quantified by using an itch scale for measuring pruritus) after up to eight weeks of exclusion diet with a novel food source of protein and carbohydrate. Thus, the possibility of AD induced by food (latu sensu) was excluded.

Sample collection. Samples were collected in the househol$\mathrm{ds}$ of the animals during the fall and winter months. The owners were contacted in advance and were instructed not to replace the beddings and to avoid the use of sprays, vacuum cleaners, and cleaning products on the day of the sample collection. Before collection, a digital humidity and temperature monitor (Incoterm 7663.02.0.00, Incoterm Inc., Porto Alegre, Brazil) was used for measuring the temperature and relative humidity of the air in the location.

Samples were collected with a portable domestic vacuum cleaner (ELECTROLUX-INGE9, Electrolux Brazil Inc., Curitiba, Brazil) containing an adaptor close to the siphon for suctioning (Dustream collection, INDOOR Biotechnologies Inc., Charlottesville, USA) so that the aspired material could be retained by a specific filter (Dustream filters, INDOOR Biotechnologies Inc., Charlottesville, USA). Between each vacuuming, the siphon was sanitized by using a $70 \%$ ethanol solution to remove allergen residues completely.

For each household, samples were collected from the places where the dogs spent the most time (dog bed and bedding, couch, floor, and carpets); each $1 \mathrm{~m}^{2}$ area was vacuumed for $2 \mathrm{~min}$.

A similar protocol was used to collect samples from the fur of the animals. The owners were contacted in advance and were instructed not to bathe or brush the dogs for at least seven days before sample collection. The animals were restrained and vacuuming was performed all over the body for $2 \mathrm{~min}$.

Following sample collection, the dust-containing filters were sealed in a plastic bag, identified, and frozen at $-6^{\circ} \mathrm{C}$ to maintain the physical integrity of the mites, avoid allergen denaturation, and inhibit mite metabolism and proliferation.

Quantification of HDMA. All dust samples collected from the households and dogs' fur were removed from the filters and were filtered through a $0.3 \mathrm{~mm}$ sieve mesh (Standard Sieve Series ASTM, Dual Manufacturing Co. Inc., Illinois, USA) to remove big particles and leave only fine dust in the Petri dishes.

For extract preparation, $100 \mathrm{mg}$ of fine dust was transferred into a test tube, and $2 \mathrm{~mL}$ of phosphate buffered saline containing $0.05 \%$ Tween 20 (PBS-T), pH 7.4, was added. For samples that were less than $50 \mathrm{mg}, 1 \mathrm{~mL}$ was added; for samples between 50 and $100 \mathrm{mg}$, an adjusted proportional volume of PBS-T was added. For resuspension, a shaker was used (VDRL Shaker TS$-2000 \mathrm{~A}$, Biotechnologies Inc., Delhi, India) for $24 \mathrm{~h}$ at $4^{\circ} \mathrm{C}$. Samples were then centrifuged at $2500 \mathrm{rpm}$ for $20 \mathrm{~min}$ at $4^{\circ} \mathrm{C}$. Supernatants (approximately $1.5 \mathrm{~mL}$ ) were collected with a Pasteur pipette into labeled Eppendorf tubes (Eppendorf Safe-Lock Tubes, Eppendorf Inc., Hamburg, Germany) and were stored at $-20^{\circ} \mathrm{C}$.

The levels of allergens Der p 1, Der f 1, and Blot 5 were determined through the validated ELISA test (Luczynska et al. 1989) using the monoclonal antibodies anti-Der p 1, anti-Der f 1, and anti-Blo t 5 (EL-DP1, EL-DF1, and EL-BT5, respectively; Indoor Biothecnologies Inc., Charlottesville, USA).

Statistical analysis. All data are presented as the averages and medians. To compare allergen concentrations between diffe- 
rent sites, the Kruskal Wallis test was used, followed by the Dunn's test for median comparison. The Spearman test was used for correlation analysis. Results were considered significant at $\mathrm{p}<0.05$. All statistical analyses were performed by using GraphPad Prism ${ }^{\circledR}$ version 5 software (GraphPad Software Inc., San Diego, California).

\section{RESULTS}

For the analysis, 147 samples from 40 households were used. Epidemiological data for both atopic dogs and healthy dogs, as well as the physical characteristics and the handling procedures at each household, are listed in Table 1.

During this study, the average environmental temperature was $18.8^{\circ} \mathrm{C}$ and the average relative humidity was $72 \%$.

Of the 147 samples collected, Der p 1 was detected in 100 samples (68\%), Der f 1 in 14 samples (9.5\%), and Blo t 5 in 9 samples (6.1\%); Der p 1 was detected at the highest concentration in the households $(0.8735 \mu \mathrm{g} / \mathrm{g} \pm$ $0.1196 \mu \mathrm{g} / \mathrm{g})(\mathrm{p}<0.00001)$ (Fig.1).

The average concentrations of the allergens Der $\mathrm{p} 1$, Der $\mathrm{f} 1$, and Blo $\mathrm{t} 5$ in the fur of atopic dogs and healthy dogs, as well as in the household dust are shown in Table 2A and 2B.

In the group of dogs with $\mathrm{AD}$, the concentrations of Der p 1 in the carpets, couches, and dog's bed linen were significantly higher than those detected in the fur of these dogs $(p<0.05)$ (Fig.2). No difference was found in the concentrations of Der $\mathrm{f} 1$ and Blo $\mathrm{t} 5$ between the different environments tested $(\mathrm{p}>0.05)$.

In the group of healthy dogs, the Der $\mathrm{p} 1$ concentrations

Table 1. Epidemiological data of the dogs with atopic dermatitis and healthy dogs, and the physical characteristics and handling procedures at the respective households

\begin{tabular}{|c|c|c|}
\hline & Dogs with AD & Healthy dogs \\
\hline Gender - Male & $05(25 \%)$ & $06(30 \%)$ \\
\hline Female & $15(75 \%)$ & $14(70 \%)$ \\
\hline Age (median) & 03 years & 5.5 years \\
\hline Age at onset of symptoms (median) & 01 year & \\
\hline Castrated $(\hat{\jmath}+)$ & $18(90 \%)$ & $14(70 \%)$ \\
\hline Fur length - Short & $08(40 \%)$ & $08(40 \%)$ \\
\hline Long & $12(60 \%)$ & $12(60 \%)$ \\
\hline Bath frequency - Weekly & $20(100 \%)$ & $20(100 \%)$ \\
\hline Shampoo used - Neutral & $03(15 \%)$ & $20(100 \%)$ \\
\hline Therapeutic & $17(85 \%)$ & 00 \\
\hline Regular use of anti-flea/anti-mite agents & $16(80 \%)$ & $14(70 \%)$ \\
\hline Regular brushing & $10(50 \%)$ & $05(25 \%)$ \\
\hline Habitat - Indoor & $20(100 \%)$ & $20(100 \%)$ \\
\hline Number of inhabitants (median) & $03(02-05)$ & $04(01-05)$ \\
\hline Number of rooms (median) & $11(10-14)$ & $09(07-12)$ \\
\hline Flooring - Floating wood tile & $12(60 \%)$ & $06(30 \%)$ \\
\hline Cold & $06(30 \%)$ & $11(55 \%)$ \\
\hline Paviflex tiles & 00 & $02(10 \%)$ \\
\hline Wood parquet & $01(05 \%)$ & 00 \\
\hline Carpet & $01(05 \%)$ & $01(05 \%)$ \\
\hline Cleaning frequency- Daily & $01(05 \%)$ & $01(05 \%)$ \\
\hline $2 \mathrm{x}$ a week & $08(40 \%)$ & $02(10 \%)$ \\
\hline $3 \mathrm{x}$ a week & $04(20 \%)$ & 00 \\
\hline $4 \mathrm{x}$ a week & $01(05 \%)$ & 00 \\
\hline Weekly & $06(30 \%)$ & $14(70 \%)$ \\
\hline Every 10 days & 00 & $01(05 \%)$ \\
\hline Fortnightly & 00 & $02(10 \%)$ \\
\hline Weekly bed linen changes & $20(100 \%)$ & $20(100 \%)$ \\
\hline Dogs bed cleaning & 00 & 00 \\
\hline
\end{tabular}

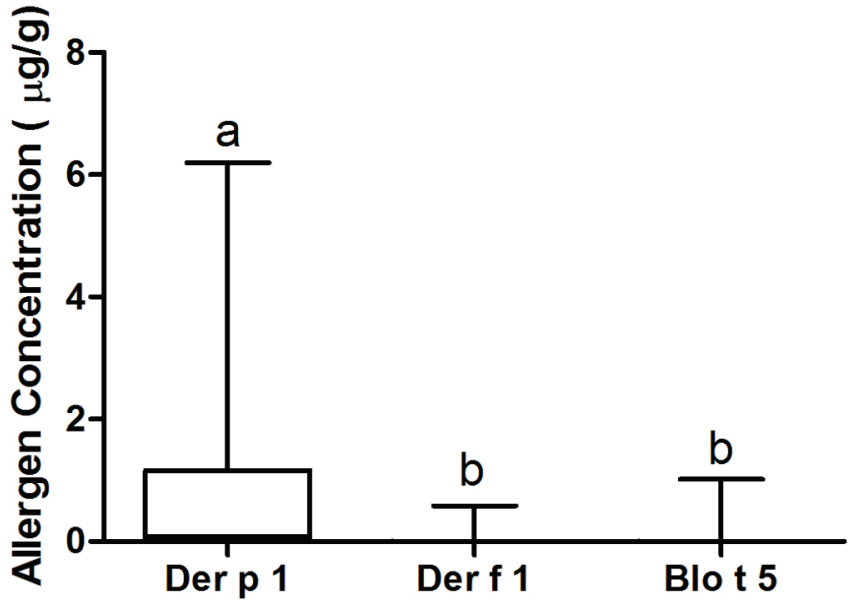

Fig.1. Concentration of Der p 1, Der f 1, and Blo t $5(\mu \mathrm{g} / \mathrm{g})$ in the evaluated samples. The letters are associated with different $p$ values for $\mathrm{p}<0.00001$.

Table $2 \mathrm{~A}$ and B. Average concentration of the allergens Der p 1, Der f 1, and Blo t $5(\mu \mathrm{g} / \mathrm{g})$ detected in household dust and in the fur of dogs with atopic dermatitis and healthy dogs. The letters correspond to different $p$ values for $p<0.05$

\begin{tabular}{|c|c|c|c|}
\hline \multirow[t]{2}{*}{ A } & \multicolumn{3}{|c|}{ Dogs with atopic dermatitis } \\
\hline & Der p 1 & Der f 1 & Blo t 5 \\
\hline Dog's bed & $1.14^{\mathrm{a}}$ & $0.00^{\mathrm{a}}$ & $0.00^{\mathrm{a}}$ \\
\hline Fur & $0.25^{\mathrm{b}}$ & $0.00^{\mathrm{a}}$ & $0.01^{\mathrm{a}}$ \\
\hline Floor & $0.14^{\mathrm{abc}}$ & $0.00^{\mathrm{a}}$ & $0.03^{\mathrm{a}}$ \\
\hline Dog's bed linen & $0.64^{\mathrm{abc}}$ & $0.00^{\mathrm{a}}$ & $0.05^{\mathrm{a}}$ \\
\hline Couch & $1.53^{\mathrm{ac}}$ & $0.02^{\mathrm{a}}$ & $0.00^{\mathrm{a}}$ \\
\hline Carpet & $2.18^{\mathrm{ac}}$ & $0.07^{\mathrm{a}}$ & $0.06^{\mathrm{a}}$ \\
\hline \multirow[t]{2}{*}{ B } & \multicolumn{3}{|c|}{ Healthy dogs } \\
\hline & Der p 1 & Der $\mathrm{f} 1$ & Blo t 5 \\
\hline Dog's bed & $1.82^{\mathrm{a}}$ & $0.05^{\mathrm{a}}$ & $0.07^{a}$ \\
\hline Fur & $0.03^{\mathrm{b}}$ & $0.00^{\mathrm{b}}$ & $0.01^{\mathrm{a}}$ \\
\hline Floor & $0.72^{\mathrm{ab}}$ & $0.00^{\mathrm{ab}}$ & $0.00^{\mathrm{a}}$ \\
\hline Dog's bed linen & $0.00^{\mathrm{ab}}$ & $0.00^{\mathrm{ab}}$ & $0.23^{a}$ \\
\hline Couch & $1.24^{\mathrm{ac}}$ & $0.04^{\mathrm{ab}}$ & $0.05^{\mathrm{a}}$ \\
\hline Carpet & $0.42^{\mathrm{abc}}$ & $0.01^{\mathrm{ab}}$ & $0.00^{\mathrm{a}}$ \\
\hline
\end{tabular}

in the couches and beds and the Der $\mathrm{f} 1$ concentrations in the beds were significantly higher than the concentrations detected in the fur of these animals $(\mathrm{p}<0.05)$. No differences were found in the Blo t 5 concentrations between the different environments tested ( $\mathrm{p}>0.05)$.

When the concentrations of Der $\mathrm{p} 1$ in the fur and in the microenvironment of dogs with AD were correlated, it was observed that the higher the concentration in the dog's bed and couch, the higher was the concentration in the dog's fur $(\mathrm{p}<0.05)$.

It was also observed that the concentrations of the mite allergens Der p 1, Der f 1, and Blo t 5 were similar between the microenvironments of dogs with $\mathrm{AD}$ and healthy dogs $(\mathrm{p}>0.05)$.

\section{DISCUSSION}

Beginning in the twentieth century, the usual behavior of families changed, and families now spend most of their time in indoor environments. This new lifestyle has increased exposure to allergens, leading to the development of 


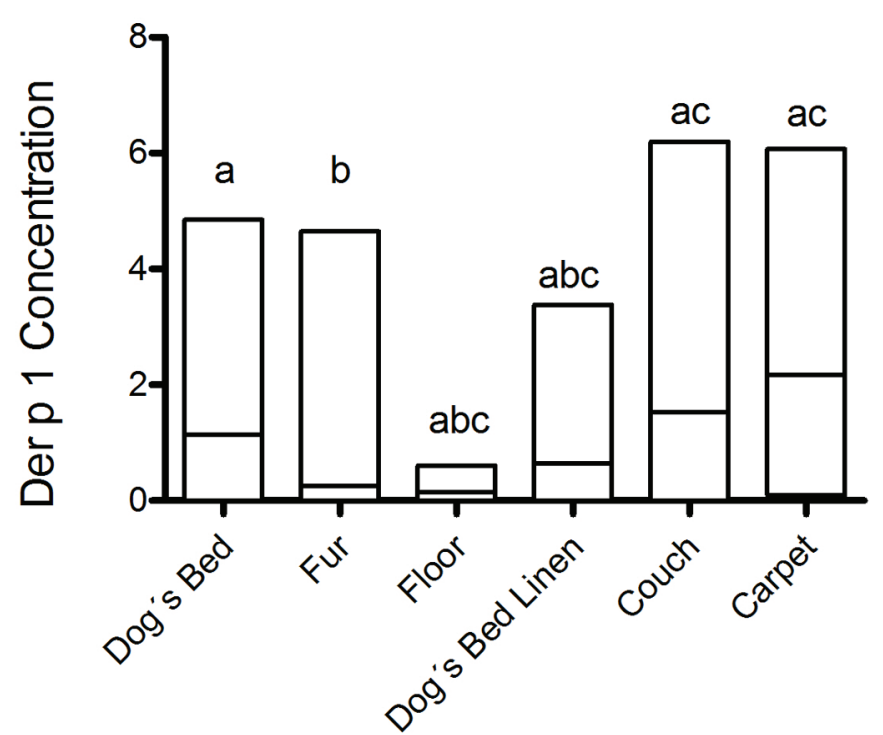

Fig.2. Distribution of Der $\mathrm{p} 1$ concentration $(\mu \mathrm{g} / \mathrm{g})$ in the different microenvironments of dogs with atopic dermatitis. The bars represent the maximum and minimum values and the lines on the bars indicate the averages. The letters correspond to different $\mathrm{p}$ values for $\mathrm{p}<0.05$.

allergic diseases (Platts-Mills 2009). Dogs have also experienced these changes because they have adapted to their owner's lifestyle; thus, these animals now live more frequently in apartments or indoors, and spend most of their time in the proximity of their owners.

Mite allergens are ubiquitous and are capable of causing allergic reactions in humans, dogs, and several other animal species (Randall et al. 2003, Gehring et al. 2005, Raffan et al. 2005, Allan \& Novak 2006).

D. pteronyssinus is abundant in Southern and Central America (Thomas 2010). Previous studies performed in various Brazilian cities (Geller 1996, Medeiros et al. 2002, Rego et al. 2003, Rullo et al. 2005) showed that Dermatophagoides pteronyssinus and Blomia tropicalis are important sensitizing agents in human patients with rhinitis and allergic asthma.

D. pteronyssinus populations grow preferably at temperatures of $25^{\circ} \mathrm{C}$ and a relative air humidity above $60 \%$ (Arlian \& Platts-Mills 2001, Jackson et al. 2005). Notably, in this study, sample collection was performed during the fall and winter months, when the average temperatures were low and the relative air humidity was approximately $72 \%$; this fact may have contributed to the maintenance of D. pteronyssinus populations and extended the viability of the mite's allergens.

The allergens from $D$. pteronyssinus are expected to play an important role in sensitizing dogs with $\mathrm{AD}$ in Brazil because they are present in house dust.

The Der p 1 allergen is a cysteine protease with a molecular weight of approximately $24 \mathrm{kDa}$; this protease is active at an acidic $\mathrm{pH}$ and is similar to the one found on the surface of mammalian skin. This allergen facilitates epithelial permeability through several mechanisms: the degradation of occludin, claudin, and junction proteins; the induction of IgE-independent inflammation mediated by basophile and mastocyte activation; the induction of IL-4 secretion; the inhibition of the development of Th1 responses, both by a direct effect on $\mathrm{T}$ cells and by modulating IL-12 secretion by dendritic cells; and the activation of a variety of cell types following PAR-2 receptor cleavage. These pro-inflammatory functions can contribute to allergic sensitization (Bizikova et al. 2015).

D. farinae and its allergens peak at temperatures between 25 and $30^{\circ} \mathrm{C}$ and a relative air humidity of 50 to $60 \%$ (Jackson et al. 2005), which may explain the lower concentrations of Der $\mathrm{f} 1$ in the microenvironments studied when compared with the concentrations detected in other Brazilian states and in countries with temperate climates.

In the northern hemisphere, the sensitization and increase of AD symptoms in dogs have been associated with exposure to $D$. farinae allergens (Nuttall et al. 2006). Western blot protein studies showed that 80 to $90 \%$ of $\mathrm{AD}$ dogs sensitized to $D$. farinae extracts have specific IgE antibodies against $D$. farinae proteins with a molecular weight between 60 and $98 \mathrm{kDa}$, suggesting that high molecular weight D. farinae allergens, such as Der f 15 and Der f 18, are the most important factors contributing to the exacerbated clinical manifestations of AD (McCall et al. 2001, Weber et al. 2003). Hou et al. (2005), characterized the IgG response to D. farinae antigens in healthy dogs and in $\mathrm{AD}$ dogs by using immunoblotting and electrophoresis techniques, and the two major bands detected corresponded to proteins with molecular weights of $98 \mathrm{kDa}$ (Der f 15) and $44 \mathrm{kDa}$. Unfortunately, no tests are available for the quantification of these allergens intradermally or in the environment, and information is not available concerning their concentration in domestic dust samples.

B. tropicalis (Blo t 5) allergens have been suggested as a frequent cause of sensitization in children with rhinitis and allergic asthma (Farias 2007). B. tropicalis can be found in tropical climates, and sensitization to these allergens is common in dogs with $\mathrm{AD}$ living in these regions (Cunha et al. 2012).

Der p 1, Der f 1, and Blo t 5 concentrations were low in the households evaluated in our study when compared with previously reported results (Farias et al. 2015). This can be explained by a combination of factors such as proper cleaning of the environment, frequent changings of the animal's bed linen, presence of floors that facilitated the cleaning process, presence of few rugs and carpets in the environment, and low number of inhabitants.

Carpets and couches were the sites with the highest concentrations of the Der p 1 allergen in the households of atopic dogs, whereas Der $\mathrm{p} 1$ accumulated mostly in the beds and couches in the households with healthy dogs. This could be because of difficulties in sanitizing these sites or because the owners reported that vacuuming or washing the beds is not customary practice.

In the remaining microenvironments studied, the allergen concentrations were similar between the environments associated with either atopic dogs or healthy dogs, indicating that both groups of dogs were equally exposed to allergens. Therefore, atopic dogs must develop clinical symptoms because of genetic defects in the epidermal bar- 
rier and in junction proteins (Cork et al. 2006, Marsella \& Samuelson 2009). Epidermal barrier dysfunction facilitates contact between the environmental and microbial allergens and the defense cells in the epidermis, which stimulates the inflammatory response in the skin (Olivry et al. 2010, Kubo et al. 2012). Changes in the microstructure of the epidermis in atopic dogs were shown to lead to pruritus and to trigger activation of the inflammatory response (Homey et al. 2006).

In this study, the low concentrations of Der p 1, Der $\mathrm{f} 1$, and Blo $t 5$ detected in the fur of atopic dogs tested may reflect the handling of these animals, which involved weekly baths, regular brushing, and maintenance in clean environments.

When the Der $\mathrm{p} 1$ allergen concentration in the fur was correlated with the microenvironment of the dogs with $\mathrm{AD}$, it was observed that the higher the concentration of this allergen in the dog's bed and couch, the higher was its concentration in the fur. Thus, the environment may have been a source of mite allergens to the dog, and these allergens are found in their fur after frequenting their ecological niches.

The mite allergen Der p 1 in the microenvironment of dogs with $\mathrm{AD}$ had a concentration higher than $2 \mu \mathrm{g} / \mathrm{g}$ of dust in the carpet. It is not currently known if Der $p 1$ is capable of sensitizing and triggering symptoms in dogs with $\mathrm{AD}$ at these concentrations.

Allergens from group 3, 6, and 9 are serine proteases that, like Group 1 allergens, can compromise epithelial integrity by interfering with cell junctions (Bizikova et al. 2015). Although these proteases comprise $80 \%$ of the total of proteases detected in house mite extracts, the concentration of these allergens was not assayed in this study. Further studies are required to establish the importance of these allergens in the development of AD in dogs.

\section{CONCLUSIONS}

Der $\mathrm{p} 1$ was the main allergen found in the dog microenvironment, especially on the couch, the dog's bed, and the carpet.

This result did not differ between the microenvironments of dogs with $\mathrm{AD}$ and healthy dogs.

Dogs can carry mite allergens on the fur after frequenting their ecological niches.

\section{REFERENCES}

Akdis C.A., Akdis M., Bieber T., Bindslev-Jensen C., Boquniewicz M., Eigenmann P., Hamid Q., Kapp A., Leung D.Y., Lipozencic J., Luger T.A., Muraro A., Novak N., Platts-Mills T.A., Rosenwasser L., Scheynius A., Simons F.E., Spergel J., Turjanmaa K., Wahn U., Weidinger S., Werfel T. \& Zuberbier T. 2006. Diagnosis and treatment of atopic dermatitis in children and adults: European Academy of Allergology and Clinical Immunology/ American Academy of Allergy, Asthma and Immunology/Practall Consensus Report. J. Allergy. Clin. Immunol. 61:969-987.

Allan J.P. \& Novak N. 2006. The pathophysiology of atopic eczema. Clin. Exp. Dermatol. 31:89-93.

Arlian L.G. \& Platts-Mills T.A.E. 2001. The biology of dust mites and the remediation of mite allergens in allergic disease. J. Allergy Clin. Immunol. 107:406-413.

Bizikova P., Pucheu-Haston C.M., Eisenschenk M.N.C., Marsella R., Nuttall
T. \& Santoro D. 2015. Review: Role of genetics and the environment in the pathogenesis of canine atopic dermatitis. Vet. Dermatol. 26:95-e26.

Brazis P., Serra M., Selle's A., Dethioux F., Biourge V. \& Puigdemont A. 2008. Evaluation of storage mite contamination of commercial dry dog food. Vet. Dermatol. 19:209-214.

Cork M.J., Robinson D.A. \& Vasilopoulos Y. 2006. New perspectives on epidermal barrier dysfunction in atopic dermatitis: gene-environment interactions. J. Allergy Clin. Immunol. 118:3-21.

Cunha V.E.S., Silva M.H. \& Faccini J.L.H. 2012. Serological identification of house dust mite allergens in dogs with atopic dermatitis. Pesq. Vet. Bras. 32:917-921.

Eaton K.K., Downing F.S., Griffiths D.A., Hockland S. \& Lynch S. 1985. Housedust mites ( $D$. pteronyssinus) in pets' beds and their relation to dust allergy. Clin. Allergy 15:151-154.

Eggleston P.A. \& Arruda L.K. 2003. Ecology and elimination of cockroaches and allergens in the home. J. Allergy Clin. Immunol. 107:422-429.

Farias M.R. 2007. Dermatite atópica canina: da fisiopatologia ao tratamento. Clin. Vet. 69:48-62.

Farias M.R., Barbosa M., Arruda L.K. \& Rosario Filho N. 2015. Evaluation of the concentration of the coat of dogs aeroallergens (Canis lupus familiaris) and the dust from families of children with asthma and or allergic rhinitis. World Allergy Organ. J. 8(Suppl.1):A171.

Farmaki R., Saridomichelakis M.N., Leontides L., Papazahariadou M.G., Gioulekas D. \& Koutinas A.F. 2012. Dust mite species in the households of mite-sensitive dogs with atopic dermatitis. Vet. Dermatol. 23:222e45.

Favrot C., Steffan J., Seewald W. \& Picco F.A. 2010. A prospective study on the clinical features of chronic canine atopic dermatitis and its diagnosis. Vet. Dermatol. 21:23-31.

Gehring U., Brunekreef B., Fahlbusch B., Wichmann H.E. \& Heinrich J. 2005. Are house dust mite allergen levels influenced by cold winter weather? Allergy 60:1079-1082.

Geller M. 1996. Alergia aos ácaros no Rio de Janeiro. J. Bras. Med. 71:164169.

Halliwell R. 2006. Revised nomenclature for veterinary allergy. Vet. Immunol. Immunopathol. 114:207-208.

Hill P.B. \& DeBoer D.J. 2001. The ACVD task force on canine atopic dermatitis (IV): environmental allergens. Vet. Immunol. Immunopathol. 81:169-186.

Hillier A. 2002. Definitively diagnosing atopic dermatitis in dogs. Vet. Med. 97:198-208.

Homey B., Steinhoff M., Ruzicka T. \& Leung D.Y. 2006. Cytokines and chemokines orchestrate atopic skin inflammation. J. Allergy Clin. Immunol. 118:178-189.

Hou C.C., Pemberton A., Nuttal T. \& Hill P.B. 2005. IgG responses to antigens from Dermatophagoides farinae in healthy and atopic dogs. Vet. Immunol. Immunopathol. 106:121-128.

Jackson P.A., Foster P.A., Hart J.B., Helps R.C. \& Shaw E.S. 2005. Prevalence of house dust mites and dermatophagoides group 1 antigens collected from bedding, skin and hair coat of dogs in south-west England. Vet. Dermatol. 16:32-38.

Kubo A., Nagao K. \& Amagai M. 2012. Epidermal barrier dysfunction and cutaneous sensitization in atopic diseases. J. Clin. Invest. 122:440-447.

Luczynska C.M., Arruda L.K., Platts-Mills T.A., Miller J.D., Lopez M. \& Chapman M.D. 1989. A two-site monoclonal antibody ELISA for the quantification of the major Dermatophagoides spp. allergens, Der $\mathrm{p} 1$ and Der $\mathrm{f}$ 1. J. Immunol. Methods. 118:227-35.

Madhurantakam C., Nilsson O.B., Konradsen J., Saarne T. \& Hogbom E. 2010. Crystal structure of the Dog Lipocalin Allergen Can f 2: Implications for Cross-reactivity to the Cat Allergen Fel d 4. J. Mol. Biol. 401:6883.

Marsella R. \& Samuelson D. 2009. Unravelling the skin barrier: a new paradigm for atopic dermatitis and house dust mites. Vet. Dermatol. 20:533538.

Medeiros Jr. M., Figueiredo J.P., Almeida M.C., Atta A.M., Taketomi E.A., Silva 
D.A., Terra S.A., Amorim W.W., Pinho R.S., Araujo M.I. \& Carvalho E.M. 2002. Association between mite allergen (Derp 1, Der f 1, Blo t 5) levels and microscopic identification or skin prick test in asthmatic subjects. Int. Arch. Allergy Immunol. 129:237-241.

McCall C., Hunter S., Stedman K., Weber E., Hillier A., Bozic C., Rivoire B. \& Olivry T. 2001. Characterization and cloning of a major high molecular weight house dust mite allergen (Der f 15) for dogs. Vet. Immunology. Immunopathol. 78:231-247.

Nuttall T., Hill P.B., Bensignor E. \& Willemse T. 2006. House dust and forage mite allergens and their role in human and canine atopic dermatitis. Vet. Dermatol. 17:223-235.

Olivry T., Deboer D.J., Favrot C., Jackson H.A., Mueller R.S., Nuttall T. \& Prélaud P. 2010. Treatment of canine atopic dermatitis: clinical practice guidelines from the International Task Force on canine atopic dermatitis. Vet. Dermatol. 21:233-248.

Platts-Mills T.A.E. 2009. Indoor allergens, p.539-555. In: Ibid. (Eds), Middleton's Allergy: principles and practice. 7 th ed. Mosby Elsevier, Philadelphia.

Raffan E., Lawrence H., Henderson T., Nelson S., Isherwood D., McArdle C. \& Nuttall T. 2005. Prevalence of the group I Dermatophagoides allergens Der p 1 and Der $\mathrm{f} 1$ in homes with no dogs, healthy dogs and Dermatophagoides-sensitized atopic dogs in Liverpool. Vet. Dermatol. $16: 253-260$
Randall A., Hillier A., Cole L.K., Kwochka K.W., Needham G. \& Wassom D.L. 2003. Quantitation of house dust mites and house dust mite allergens in the microenvironment of dogs. Am. J. Vet. Res. 64:1580-1588.

Rego F.X., Barros M.T., Matos G., Kalil J., Bruim P.F.C., Tobias K.R., Chapman M.D. \& Arruda L.K. 2003. Hammocks as important source of exposure to mite allergen in northeast Brazil. J. Allergy Clin. Immunol. 111(2):S239.

Rullo V.E., Solé D., Arruda L.K., Nakamura C., Valente V., Nóbrega F.J. \& Naspitz C.K. 2005. Exposição a alérgenos e a endotoxina, sensibilização e expressão clínica da doença alérgica: estudo de coorte. Revta Bras. Alerg. Imunopatol. 28:292-297.

Thomas W.R. 2010. Geography of house dust mite allergens: review article. Asian Pac. J. Allergy Immunol. 28:211-224.

Upham J.W. \& Holt P.G. 2005. Environment and development of atopy. Curr. Opin. Allergy Clin. Immunol. 5:167-172.

Zavadniak A.F. 2000. Verificação da potência de extratos alergênicos e da exposição à alérgenos domiciliares: contribuição ao tratamento de doenças alérgicas. Dissertação de Mestrado, Universidade Federal do Paraná, Curitiba.

Weber E., Hunter S., Stedman K., Dreitz S., Olivry T., Hillier A. \& McCall C. 2003. Identification, characterization, and cloning of a complementary DNA encoding a 60-kd house dust mite allergen (Der f 18) for human beings and dogs. J. Allergy. Clin. Immunol. 112:79-86. 